\title{
The issues of legal and regulatory support for the implementation of resource-saving, energy- saving and best available technologies in urban development
}

\author{
Ilya Yazhlev", Dmitry Spitsov² and Alexander Popkov",** \\ ${ }^{1}$ Environmental insurance association, 15/14/1, Tverskaya str., 125047, Moscow, Russia \\ ${ }^{2}$ Moscow architectural Institute, bld. 4, 11/4, Rozhdestvenka str., Moscow, Russia \\ ${ }^{3}$ Moscow State University of Civil Engineering, 26, Yaroslavskoye Shosse, 129337, Moscow, Russia
}

\begin{abstract}
The article is devoted to the problems of the development of environmental and industrial legislation in Russian Federation with regard to transition to the new principles of environmental management, to reduce negative impacts on the environment through the modernization of basic production assets, the use of innovative methods of management of production processes and business entities.
\end{abstract}

\section{Introduction}

Generally, the object and content of studying ecology as a science is the interrelation of various ecosystems with the environment. One of these systems is an urbanized environment, artificially created and very dynamically developing. For instance, Moscow is doubly ahead of similar global megacities in terms of growth in construction volumes in the ranking of world cities, our capital is in third place in terms of travel and transport construction [1]. Every year, more than 40 bln rubles are allocated for the improvement of urban areas. By different estimations, up to 3 mln cubic meters of soil are moved in the city every year during construction works [2]. Of course, this pattern carries certain environmental challenges and threats both for the population and for the city's environment as a whole.

In this regard, particular attention should be paid on the issues of legal and regulatory support, organizational aspects, methods for implementing the best available technologies and modernizing the urban economy of Russian cities.

In accordance with the Federal law"On environmental protection"of 10.01.2002 No. 7FZ (ed. of 03.07.2016), the best available technology (BAT) is" technology for production of goods, performance of works, provide services, determined on the basis of modern achievements of science and technology and the best combination of criteria for achieving the goals of environmental protection, provided that it is technically possible to use it»[3].

The conversion of industries to the best available technologies was started in 2014 after the adoption of Federal law No. 219-FZ of 21.07.2014 concerning amendments to the

${ }^{*}$ Corresponding author: doptaganka@yandex.ru 
Federal law "On environmental protection" , according to which enterprises and organizations must implement cost-effective technologies that minimize the negative impact on the environment, waste generation and emissions. The entire process of transition to the best available technologies (BAT), according to preliminary estimates, will take from 7 to 14 years and should reduce the level of negative impact in the Russian Federation by $75-80 \%[4]$.

In order to fulfil the regulations of the law, a number of legislative and regulatory acts have been issued that regulate the development of information and technical reference books on BAT containing basic information about the environmental impact standards of enterprises.

Primarily the best available technologies in the construction can be considered for implementation in the innovative areas of so-called "green building", resource, energy saving and energy efficiency, production of building materials, as well as in the field of territorial planning, in particular, reorganization, redevelopment of urban areas and their environmental rehabilitation.

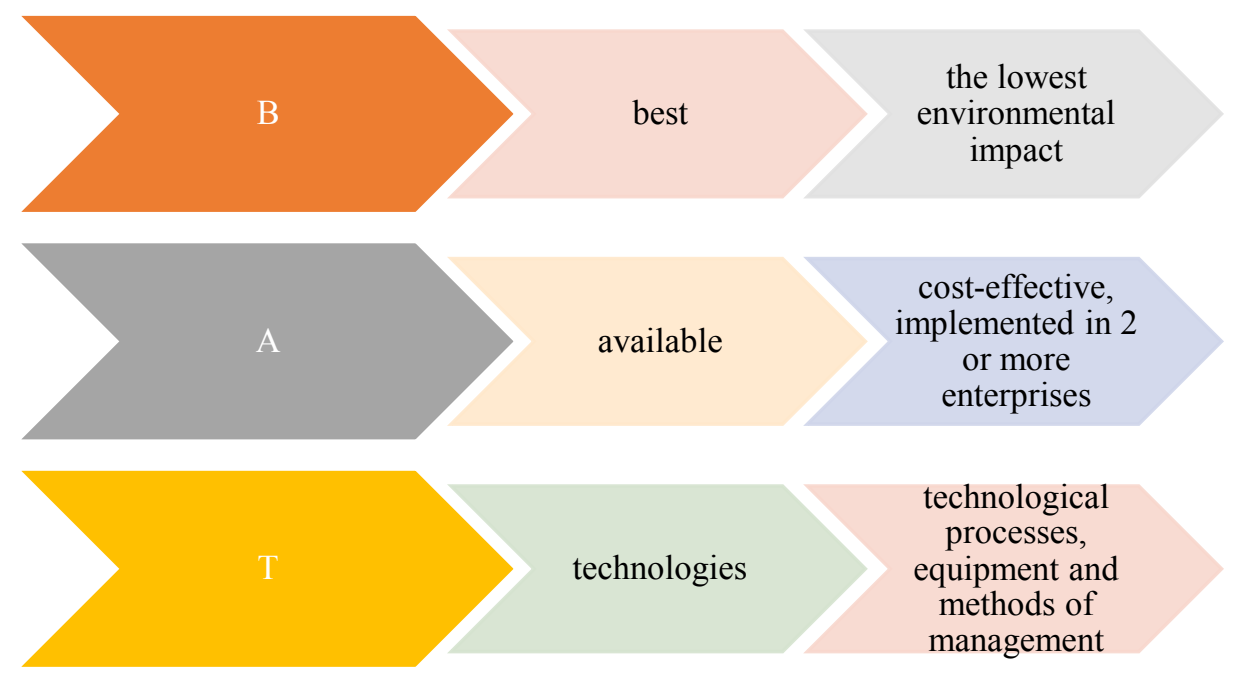

Fig. 1. Criteria for best available technologies.

According to "The rules for determining technology as the best available technology, as well as the development, updating and publication of information and technical reference books on the best available technologies" approved by the government of the Russian Federation resolution No. 1458 of December 23, 2014, the working groups under the Federal Agency for technical regulation (Rosstandart) develop, approve and publish industry-specific information and technical reference books on the best available technologies (BAT).

The application of the best available technologies is taken as the basic principle for regulating the activities of enterprises and organizations that have a negative impact on the environment in most countries. "Available" refers to those technologies that are developed taking into account economic and technical realities, "best" - the most effective for achieving a high level of environmental protection (Fig. 1.). 


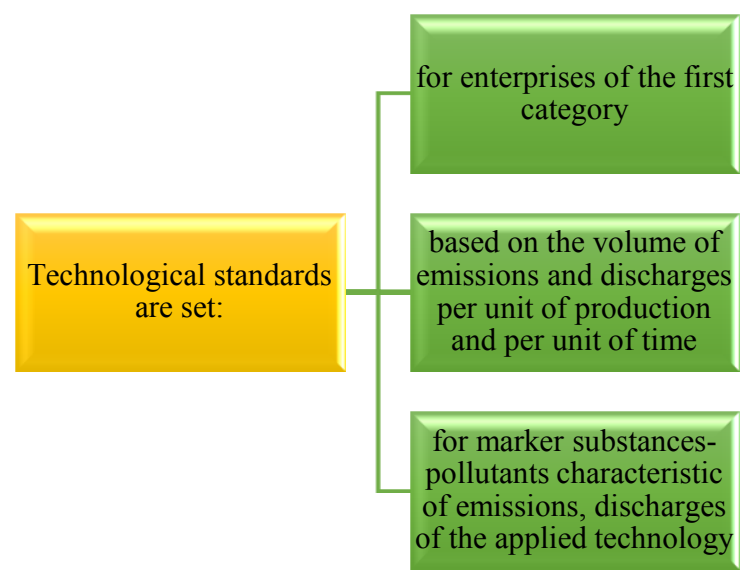

Fig. 2. Environmental regulation based on BAT (technological regulation).

The economic and environmental reasons for the modernization and BAT implementation in enterprises and the Russian economy sectors are defined by documents adopted by the leadership of our country. Presidential decree No. 176 of 19.04.2017 "On the environmental security strategy until 2025" and presidential decree No. 208 of 13.05.2017 "The economic security Strategy until 2030" define today's environmental challenges and threats to the urban environment. Among them, the consequences of climate change on the planet are identified as global environmental security challenges, among the industrial sectors that produce greenhouse gases the construction industry, wastewater treatment, and waste management of production and consumption are specified.

The Kyoto Protocol, adopted in December 1997. Kyoto (Japan) is an international agreement, an additional document to the UN framework Convention on climate change from 1992. It obliges developed countries and countries with transition economies to reduce or stabilize greenhouse gas emissions (methane, carbon dioxide, nitrogen oxide, fluorinated gases). Then the Paris agreement of 2015. regulating measures to reduce carbon dioxide in the atmosphere from 2020. among the industries - sources of greenhouse gases arealso defined the construction industry, waste water treatment, waste management of production and consumption.

Another global challenge is the growing consumption of natural resources. The reduction of easily recoverable natural resource reserves has stimulated the production of shale gas and oil in the United States. Their extraction technologies have a very negative impact on the environment in the areas where the deposits are located.

Almost everywhere there is a reduction in biological diversity. Due to the increase in the cost of urban land and the desire to achieve the maximum economic effect from their use, there is a reduction in the area of green spaces, natural objects in cities and an increase in the negative consequences of environmental degradation for the population of primarily urbanized areas.

In Russia, high depreciation of basic production assets, low rates of technological modernization of the economy, and insufficient development and implementation of environmentally friendly technologies are identified by presidential decrees as internal challenges to environmental safety. According to the State report "On the state of the environment of the Russian Federation in 2018", 96 Russian cities have a high level of air and water pollution.

Although in recent years the level of waste recycling has increased from $40 \%$ of the total volume to $53 \%$, there is an increase in the volume of production and consumption waste. Only Moscow produces up to 15 million tons of waste per year. In Russian regions, 
more than 31.5 billion tons of waste has been placed at landfills and unauthorized dumps, of which 14 thousand tons are of the 1st hazard level. Accumulated environmental damage, increased land and soil degradation, brownfields mainly within urban areas and industrial zones, remain a significant problem [5].

The master plan for thecity development of almost every major industrial center contains sections on the reorganization of industrial zones. In Moscow, such zones make up $16 \%$ of the city's territory with a much larger area of negative impact. The result of unfavorable conditions is a reduction in the species diversity of the plant and animal world[6].

\section{Methods}

Solutions to the problems of development of legal and regulatory support for the implementation of resource -, energy-saving and best available technologies in urban development and improvement of the legislative framework is one of the important steps in terms of responding to these challenges. The legal framework for the implementation of resource -, energy-saving and best available technologies in urban development includes federal laws, regional legislative acts, standardization documents, regulatory acts of executive authorities, international documents and obligations of the Russian Federation.

The Federal law "On environmental protection" of 10.01.2002 No. 7-FZ (as amended on 03.07.2016 No. 358-FZ) is a fundamental legal act in the system of environmental legislation. It combines the main directions of rational nature management and environmental protection. The law regulates all aspects and relations of activities in urban areas. It establishes general requirements in the field of environmental protection, including during the placement, design, construction, reconstruction, commissioning, operation, conservation and liquidation of buildings, structures and other objects, as well as requirements in the field of environmental protection during the placement, design, construction, reconstruction of urban and rural settlements.

Table 1. Measures of state regulation depending on the category of industrial facility.

\begin{tabular}{|c|c|c|c|}
\hline $\begin{array}{c}\text { Industrial } \\
\text { facility with significant } \\
\text { environmental impact }\end{array}$ & $\begin{array}{c}\text { Industrial } \\
\text { facility with } \\
\text { moderate } \\
\text { environmental } \\
\text { impact }\end{array}$ & $\begin{array}{c}\text { Industrial } \\
\text { facility with } \\
\text { little } \\
\text { environmental } \\
\text { impact } \\
\end{array}$ & $\begin{array}{c}\text { Industrial } \\
\text { facility with } \\
\text { minimal } \\
\text { environmental } \\
\text { impact }\end{array}$ \\
\hline State ecological expertise & No & No & No \\
\hline \multicolumn{4}{|c|}{ Official registration of objects that have a negative impact on the environment } \\
\hline Regulation based on BAT & $\begin{array}{l}\text { Declaring the amount of } \\
\text { negative impact on the } \\
\text { environment }\end{array}$ & No & No \\
\hline \multicolumn{4}{|c|}{$\begin{array}{l}\text { Industrial environmental control } \\
\text { (Differentiation by categories of industrial facilities) }\end{array}$} \\
\hline $\begin{array}{l}\text { Equipping sources of } \\
\text { emissions and discharges } \\
\text { of pollutants with } \\
\text { permanent monitoring } \\
\text { devices }\end{array}$ & No & No & No \\
\hline \multicolumn{4}{|c|}{ Reporting on the amount of negative impact on the environment } \\
\hline \multicolumn{3}{|c|}{ Reporting on the realization of BAT implementation plans and programs } & No \\
\hline $\begin{array}{l}\text { Federal state } \\
\text { environmental } \\
\text { supervision }\end{array}$ & Reginal state environmen & supervision & $\begin{array}{l}\text { Only unscheduled } \\
\text { inspections }\end{array}$ \\
\hline
\end{tabular}


In recent years, the most significant changes to existing approaches to state regulation in the field of environmental protection have been the provisions of Federal law No. 219-FZ of 21.07.2014 "On amendments to the Federal law "On environmental protection" and certain legislative acts of the Russian Federation", which are expected to enter into force in the period from 2015 to 2020. In accordance with the provisions of the law, the concept of "best available technology" (BAT) is introduced; the system of environmental regulation based on BAT is being improved (Fig. 2.); a system of integrated environmental permits based on BAT is being introduced; regulatory regimes for large and small sources of pollution are being differentiated (Table 1.); economic incentives are being provided for economic entities to introduce BAT (Fig. 3); and public participation and access to information are being provided in the process of modernizing production facilities.

In accordance with the "Urban development code of the Russian Federation" (Federal law No. 190-FZ of 29.12.2004), urban development activities are activities for the development of territories, including cities and other settlements, carried out in the form of territorial planning, urban zoning, territory planning, architectural design, construction, capital repairs, reconstruction of capital construction objects, operation of buildings and structures. The law defines the main provisions of sustainable development of territories.

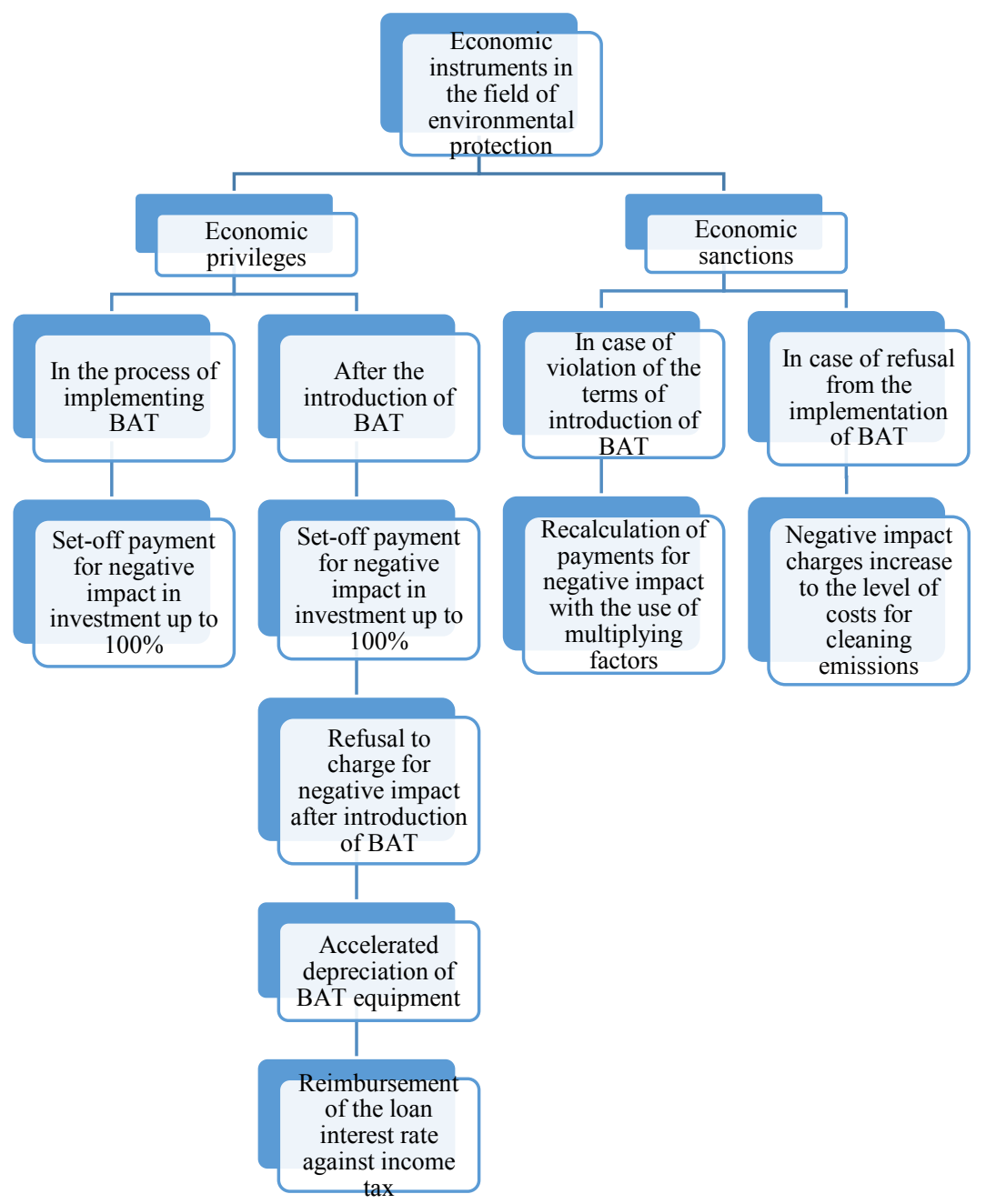

Fig. 3. Economic incentives for the implementation of BAT. 
The objectives of the "Technical regulations on the safety of buildings and structures", Federal law No. 384-FZ of 30.12.2009, are to protect the life and health of citizens, property of individuals or legal entities, state or municipal property; to protect the environment, life and health of animals and plants; to prevent actions that mislead buyers; to ensure the energy efficiency of buildings and structures. It sets the minimum necessary requirements for buildings and structures, for engineering support networks and engineering support systems that are part of them, as well as for design processes related to buildings and structures (including surveys), construction, installation, commissioning, operation and disposal (demolition) in the field of mechanical safety; fire safety; safety in hazardous natural processes and technogenic impact; safe living conditions for human health in buildings and structures; safety for users of buildings and structures; accessibility of buildings and structures for disabled people and other groups of the population with limited mobility; energy efficiency of buildings and structures; safe level of impact of buildings and structures on the environment.

In accordance with Federal law No. 162-FZ of 29.06.2015 "On standardization", the objectivities of national standards in the field of energy and resource conservation and the introduction of the best available technologies are to stimulate the technical re- equipment of industry, improve the quality of products, perform work, provide services and increase the competitiveness of Russian -made products.

\section{Results}

One of the main normative documents in the field of implementation of the best available technologies are the documents on standardization- information and technical reference books. In accordance with the decree of the RF Government dated 31.10.2014 No. 2178-R (edition of 07.07.2016) information-technical manuals on best available techniques is a standardization document developed for a specific industry, containing the best solutions and description of technologies, processes, methods of application and management to reduce impact on the environment.

\section{Discussion}

If the Russian legislation does not contain legislative norms, which can be used for implementation of BAT, it is possible to use the corresponding analogues of the model legislation of the CIS member States. This is a type of international legislation. Model laws are adopted by the Interparliamentary Assembly of the CIS countries. Its rules are advisory in nature. However, firstly, they are harmonized with the legislation of all CIS countries, and secondly, some countries often adopt them as mandatory norms in the form of national legislation.

To effectively implement these requirements, it is necessary to intensify the development and adoption of national standards such as, for example, GOST R 57446-2017 "Best available technologies. Environmental remediation of contaminated soil and brownfields. Recovery of biological diversity", which sets out the main provisions for the environmental rehabilitation of polluted land in urban settlements [7,8,9,10,11]. Documents on standardization will allow nature users to specify the requirements of Federal legislation and, on the other hand, provide methodological support for the implementation of the proposed measures. 


\section{Conclusion}

Solving the problems of developing regulatory support for the implementation of resource-, energy-saving and best available technologies in urban planning and improving the legislative framework is one of the important steps in terms of responding to these challenges. The regulatory framework for the implementation of resource-, energy-saving and best available technologies in urban planning includes federal laws, regional legislative acts, standardization documents, regulatory acts of executive authorities, international documents and obligations of the Russian Federation.

\section{References}

1. Materials of the meeting of the annual board of the Complex of urban planning policy and the construction of the capital (2015) https://stroi.mos.ru/news/v-moskve-samyevysokie-v-mire-tempy-rosta-obemov-stroitelstva-sobyanin? $\mathrm{from}=\mathrm{cl}$

2. $R B C$, https://realty.rbc.ru/news $/ 58 \mathrm{~d} 27 \mathrm{df} 89 \mathrm{a} 7947 \mathrm{edcf} 3 \mathrm{cc} 8 \mathrm{~d} 4$

3. Federal Law "On Environmental Protection" 10.01.2002 №7-Ф3 (2018), http://www.consultant.ru/document/cons_doc_LAW_34823/

4. Federal Law "On Amending the Federal Law" On Environmental Protection "and Certain Legislative Acts of the Russian Federation" 21.07.2014 N219-Ф3, http://www.consultant.ru/document/cons_doc_LAW_165823/

5. State report "On the State and Environmental Protection of the Russian Federation in 2018”, http://mnr.gov.ru/docs/gosudarstvennye_doklady/

6. I.K. Yazhlev, Environmental economics 3, 94-112 (2011) https://search.rsl.ru/ru/record/02000011241

7. A. Mottaeva, MATEC Web of Conferences 170, 01053 (2018) doi: 10.1051/matecconf/201817001053

8. E. Ganebnykh, T. Burtseva, N. Mironova, and O. Feoktistova, E3S Web of Conferences 110, 01077 (2019) DOI: 10.1051/e3sconf /201911001077

9. G. Semenova, E3S Web of Conferences 138 (2019) https://doi.org/10.1051/e3sconf/201913802012

10. Russian Federation Standard GOST 57446-2017 "Best available techniques. Disturbed lands reclamation. Restoration of biological diversity", http://docs.cntd.ru/document/1200145085

11. A. Mottaeva, A. Ivashchenko, A. Ryattel, E3S Web of Conferences 164, 10038 (2020) /https://doi.org/10.1051/e3sconf /202016410038 